İş ve İnsan Dergisi I The Journal of Human and Work

Y1l | Year: Nisan | April 2020

Cilt-Say1 | Volume-Issue: 7 (1)

ss I pp: $89-104$

doi: $10.18394 /$ iid. 553308

e-ISSN 2148-967X

https://dergipark.org.tr/tr/pub/iid

\author{
Araştırma Makalesi
}

\title{
Çalışma Mutluluğu Düzeyi ve Algısı: Özel Sektör Avukatları Üzerine Bir Araştırma
}

\author{
Level and Perception of Happiness at Work: A Study on Private Sector Lawyers
}

\begin{abstract}
Nuray Turan
\section{MAKALE BİLGİSI}

Anahtar Kelimeler:

Pozitif Psikoloji, Pozitif Çalışma Psikoloji, Çalışma

Mutluluğu, Isveren Avukat, Iş̧̧i Avukat, Şirket Avukatı

Tarihler:

Gelis 12 Nisan 2019

Düzeltme geliş 11 Eylül

2019

Kabul 26 Eylül 2019

ÖZ

Bu çalıșmanın amacl, özel sektör avukatları arasında çalıșma mutluluğunu ölçmek, çalışma mutluluğunu nasıl ifade ettiklerini ve alglladıklarını ortaya koymaktadır. Bu amaçla, 168 özel sektör avukatının katıldı̆̆ bir karma araștırma yöntemi tasarlanmıștır. Avukatların genel çalışma mutluluğu ortalamasının 5 'li likert ölçeğine göre 3,07 ile ortalama düzeyde olduğu görülmüștür. Avukatlar çalışma mutluluğunu "potansiyeli gerçekleștirme, çalışma ortamı koşullarl, huzur, işi severek yapma, para/gelir/ücret” olarak ifade etmektedir. Çalışma mutluluğunu gelir/para/ücret ile ifade eden avukatların genel çalışma mutluluğu 3,24 ortalama ile diğerlerine göre en yüksek ortalamaya sahiptir. Çalışma mutluluğunu "potansiyeli gerçekleștirme" ile ifade eden avukatların olumlu duygularl "huzur" ile ifade eden avukatlardan; "huzur ve para/ücret/gelir" ile ifade eden avukatların ise; "işini severek yapma" ile ifade eden avukatlardan daha yüksektir.
\end{abstract}

\section{A R T I C LE INFO}

\section{Keywords:}

Positive Psychology

Happiness at Work,

Employer Lawyer, Labor

Lawyer, Internal Lawyer

Article history:

Received 12 April 2019

Received in revised form 11

September 2019

Accepted 26 September 2019

\begin{abstract}
A B S T R A C T
The aim of this article is to measure happiness at work among private sector lawyers and to reveal how they express and perceive happiness at work. To this purpose, a mixed research methodology with 168 private sector attorneys was designed. The average happiness at work of the lawyers was found to be 3.07 on the 5-point Likert scale. Lawyers express their happiness at work with" realizing the potential, working environment conditions, peace, doing the job with pleasure, money / income / wage”. The general happiness at work of the lawyers who expressed their happiness at work in terms of income / money / wages has the highest average with 3.24 average. The positive feelings of the lawyers who expressed their happiness at work with revealing "own potential" an are those of the lawyers who expressed their positive feelings with "peace"; "peace and money / wages / income" stated in the lawyers; It is higher than the lawyers who express yapma doing their job with pleasure ".
\end{abstract}

\footnotetext{
a İletişim kurulacak yazar, Araş. Gör., Karamanoğlu Mehmetbey Üniversitesi, Çalışma Ekonomisi ve Endüstri İlişkileri Bölümü, Karaman,Türkiye.E-mail: nurayturan@yahoo.com. ORCID:0000-0001-6823-3992
} 
"hayat, insanoğluna der ki: 'senin zamanın doldu! ölüm vakti geldi!' Insanoğlu cevap verir: 'hepsi bu mu? bir dakika, bu benim başıma gelemez, daha yaşamaya başlamadım bile! Kazanmam gereken o kadar para nerede?! (Csikszentmihaly'nin (1990) Aklş: Mutluluk Bilimi" adll eserinden)

\section{GİRIŞ}

Çalışma yaşamı, günümüzde cinsiyet fark etmeksizin çalışmayı tercih eden insanların en fazla zaman ayırdığı bir alan haline gelmiştir ve psikolojik iyilik hali, mutluluk gibi olumlu duygular üzerinde önemli etkenlerden biri olarak kabul edilmiştir. Çalışma yaşamı ise, pek çok insan için, gerek maddi kazanç gerekse manevi kazanç açısından hayat kalitelerinin bir belirleyicisi olarak algılanmaktadır. Ancak, insan yaşamının bu denli merkezi bir alanı olan çalışma ile çoğu kişinin nihai hedeflerinden biri olan mutluluk olgularının bir araya gelerek, mutluluğun çalışma yaşamındaki varlığı ya da yokluğu; içeriği, düzeyi ve algısına yönelik yeterli bir çalışma yoktur. Oysa mutluluk insanlar için hem yaşamın geneli hem de çalışma yaşamı açısından oldukça önemsenen bir faktördür. Çalışma mutluluğu araştırmalarının diğer örgütsel davranış araştırmalarına göre sığ kaldığ1 söylenebilir. Bunun nedenleri çeşitlilik göstermektir. Bunlardan biri; somut olarak toplumun mutluluk konusunda işyeri ve çalışma psikologları tarafindan kaydedilen ilerlemenin farkında olmamasıdır. Fakat, mutluluğun ve mutsuzluğun yönü mesleki araştırmaların ana hedefleri arasındadır ve çalışma mutluluğunun doğası, kaynakları ve sonuçlarına yönelik araştırmalar yapılmıştır (Judge, Thoresen, Bono \& Patton, 2001; Kinicki, McKee-Ryan, Schriesheim \& Carson, 2002). Bir başka açıdan literatürde çalışma psikolojisi ve örgütsel davranış kapsamında tükenmişlik, iş stresi, monotonluk, psikolojik taciz, yüklenme ve zorlanma, yabancılaşma gibi çalışanı fiziki ve psikolojik olarak olumsuz etkileyen durumlara odaklanan ve çözüm önerileri sunan araştırmalar ile motivasyon, işe bağlılık, örgütsel bağlılık, sadakat ve iş doyumu olumlu etkileyen durumları merkezine alan araştırmalar oldukça fazladır. Buna karşın çalışma mutluluğunun göz ardı edilmiştir. $\mathrm{Bu}$ nedenle de çalışma mutluluğu araştırmalarının yeterince gelişemediği söylenebilir. Ayrıca bahsi geçen araştırmalar örneklem, meslek, sektör, kültür gibi değişkenler bağlamında da sıklıkla araştırılmış; ancak çalışma mutluluğuna yönelik araştırmalar o kadar yaygınlık kazanmamıştır. $\mathrm{Bu}$ noktada, çalışma mutluluğunun temel psikoloji ve çalışma psikolojisi konuları arasına diğer konular kadar girememiş olduğu söylenebilir.

Uluslararası araştırmalarda işyerinde ya da çalışma ortamında mutluluk ve iyi olma anlayışını geliştirebilecek çeşitli konulara yer verilmekte ve araştırmacılar bu alanda daha fazla teşvik edilmektedir (Rodríguez-Muñoza \& Sanz-Vergel, 2013). Ülkemizde ise; bu alandaki teorik ve uygulamalı çalışmalar, özellikle örneklem ve sektör çeşitliliğinde yetersiz kalmıştır. Çalışmanın mutluluk getirip getirmeyeceği konusundaki yanlış algılar, çalışmanın sonunda elde edilen çıktı olarak mutluluğun çoğunlukla yalnızca para ya da gelire bağlanmış olması, çalışma ve mutluluk konularının bir arada olup olmayacağı yargılaması; ayrıca çalışmanın zaman zaman yorgunluk ve eziyet sebebi gibi olumsuzlanması çalışma mutluluğu araştırmalarının sı̆̆ kalışının diğer bazı nedenleridir. İnsanların ve zihinsel süreçlerinin farklı ortamlarda benzer olduğu göz önünde bulundurulduğunda, çalışma yaşamının konuları ile psikoloji alanlarındaki çalışmalar bir araya getirilebilir (Warr, 2017). Öte yandan, 2000'li yıllarda uluslararası ölçekte, araştırmacılar ve politikacılar mutluluğu yaşam kalitesi indeksi olarak kullanma ile daha fazla ilgilenmeye başlamışlar, mutluluğun, sosyal bir gösterge olarak kullanılmasının faydalarını incelemişlerdir. Tüm insanlık faaliyetlerinin nihai hedefinin bir ölçütü olarak mutluluğun içsel açıdan değerli ve geniş yelpazedeki olumlu sonuçların yordayıcısı, değişen toplumsal koşul etkilerinin göstergesi olarak dişsal bağlamda değerli olduğu savunulmuştur. $\mathrm{Bu}$ nedenle zenginlik, çalışma ve işsizlik örneklerini kullanarak, nesnel toplumsal koşul değişimlerinin kişisel ve ulusal mutluluğu etkilediğini ortaya koymuşlardır (Tay, Kuykendall \& Diener, 2015). Böylece, ilerleyen yıllarda en sık kabul edilen görüşlerden biri çalışmanın ya da işin refah ve mutluluğa büyük ölçüde katkıda bulunduğu inancı olmuştur (Rodríguez-Muñoza \& Sanz-Vergel, 2013). Bu gelişmeler dikkate alınmış ve gözlenmiştir. Böylece, ülkemizde çalışma mutluluğu araştırma ve uygulamaları kapsamındaki çalışmaları arttırabilmek, çalışma mutluluğuna yönelik farkındalık yaratabilmek, pozitif psikolojinin çalışma yaşamına yansıyan bir yanı olarak çalışma mutluluğuna yönelik veri çeşitliliği oluşturmak ve ilgili alandaki kaynakları zenginleştirmek için bu araştırma tasarlanmıştır. $\mathrm{Bu}$ kapsamda makalede öncelikle çalışma mutluluğunun literatür kısmına yer verilmiş, ardından nicel ve nitel veriler analiz, nicel ve nitel analiz sonucunda ortaya çıkan bulgular karşılaştırılmış ve yorumlanmıştır. Son olarak sonuç ve tartışma kısmına yer verilmiştir. 


\section{CALISMA MUTLULUĞU VE ALGISI}

Mutluluk kavramının ne olduğunu tam olarak ifade etmek ve tanımlamak kolay değildir. Mutluluğun, belirsiz bir kavram niteliğinde algılanmasının yanında, ruhani algılanan bir özelliği de vardır. Çünkü mutluluk inançlar, ruh halleri, kişisel inançlar, özel durumlar ve kişinin mutluluk kavramını ne amaçla kullandığı ya da kullanırken ne demek istediğine kadar pek çok unsurla ilişkilidir (Fernández, Gamez, Aragón \& Gil, 2017). Başka bir ifadeyle mutluluk, öznel bir deneyimdir ve zaman zaman insanların mutlu olduklarına inandıkları ölçüde mutlu oldukları öne sürülür. $\mathrm{Bu}$ nedenle bazı bilim insanları mutluluğu çeşitli bileșenlerden oluşan çok boyutlu bir yap1 ve psikolojik iyilik hali olarak ele alma eğilimindedirler (Grant, Christianson \& Price 2007).

Pozitif psikolojinin yükselişi öncesinde hastalık, depresyon, stres gibi olumsuz durumlar ile sonuçları üzerine yoğunlaşan çalışmalar, mutluluğa ve diğer pozitif psikolojik durumlara göre daha sik ele alınmıştır (Erselcan \& Süral Özer, 2018). Ancak, 2000'li yılların başında pozitif psikolojinin yükselişi, çalışmanın insan yaşamına maddi getirisinin ötesinde psikolojik açıdan olumlu katkılarına yönelik ilginin artmasını; esenlik ya da işte olumlu duygulanım deneyimleri gibi olumlu olguların daha çok dikkate alınmasını sağlamıştır (Rodríguez-Muñoza \& Sanz-Vergel, 2013). Böylece, insanlar için çalışmanın sağlayacağ 1 olumlu psikolojik durumların farkına varılmıştır.

Çalışma mutluluğu, kişinin bireysel mutluluğunu ifade etmekten ziyade bir bütün olarak çalışma ortamının mutluluğunu (Porter, Lawler \& Hackman, 1975); çalışanın organizasyon içindeki birey olarak mutluluğunu ifade eder. Çalışanın işyerinde ve yaşamında ne kadar mutlu olduğu (Tosten, Avcı \& Şahin, 2017), başka bir ifadeyle çalışanların genel yaşamlarından da ne kadar mutlu olduklarını ifade eder (Saari \& Judge, 2014). Ancak, insanların çalışma mutluluğuna yönelik algıları ile çalışma mutluluğunun onlar için ne ifade ettiği görecelidir. 83 Çalışanın katıldığı bir araştırmada, adaleti amaçlayan etik ile ilişkili uygulama kurallarının (Rodríguez-Muñoza \& Sanz-Vergel, 2013), 204 çalışan arasında yapılan bir başka araştırmada ise; çalışmada anlam ve maneviyat, olumlu duygulanım ve iş tatmininin çalışma mutluluğunu ifade ettiği ortaya çıkarmıştır (Golparvara \& Abedini, 2014). $\mathrm{Bu}$ iki farklı araştırmada belirtilen işin kendisi ve çalışma ile ilgili olduğu söylenebilir. Bir başka araştırmada ise; çalışanın bireysel olarak işyerinde psikolojik sermaye boyutlarına (öz-yeterlilik, umut, dayanıklılık ve iyimserlik) yüksek düzeyde sahip olmasının çalışma mutluluğu olarak algılandığ sonucuna varılmıştır (Joo \& Lee, 2017). Tanımlarında da değinildiği gibi, çalışma mutluluğu işyerinde ya da çalışma ortamında negatif duyguların azlığı ve pozitif duyguların yaygınlığı, çalışanın potansiyel becerilerini geliştirip sürdürebilmesini, yaşamda kendini gerçekleştirmesini sağlayan amaçları başarabildiği algısıdır. (Paschoal \& Tamayo, 2008). Üzücü veya can sıkıcı duyguların yok olması, stresin azlığı ve duygusal tükenmenin yokluğu; psikolojik iyilik hali ve mutlu hislerin var olmasidır (Fredrickson, 2004). Böylece, çalışma mutluluğunun farkına varılan, gözlenen ve derecelendirilebilen bir olgu olduğunu çalışma ortamından hoşnutluk, keyif alma ve bu olumlu duyguların yaşama yansıması, olumsuz duygularla baş etme ile tanımlanabildiğini söylemek mümkündür.

\section{ARASTIRMANIN AMACI VE ÖNEMI}

Pek çok çalışanın genel yargısı, çalışma mutluluğundan söz edebilmek için çalışırken ya da çalışma ortamında olumsuz bir duygu yaşanmayacağ yönündeki düşünce ve inançlarıdır. $\mathrm{Bu}$ yanılgıları önleyebilmek, bir farkındalık oluşturabilmek önemlidir. Örneklem çeşitliliğinde çalışma mutluluğu araştırmalarının çoğaltılması; farklı mesleklerde çalışma mutluluğunun ne ifade ettiğini, düzeyinin ne olduğunu belirlemeye yönelik araştırmalar çalışma mutluluğunun kavramsal bir kaynak oluşturabilir. $\mathrm{Bu}$ sayede, çalışma mutluluğuna yönelik derinlikli çalışmaların artacağı, çalışma yaşamı kalitesi ve çalışanların pozitif duygu durumlarının geliştirilmesine katkıda bulunacak uygulamaların oluşturulmasında bir kaynak sağlanacağı öngörülmektedir. $\mathrm{Bu}$ nedenle, bu makalede "özel sektör avukatları için çalışma mutluluğu ne ifade eder, onlar tarafindan nasil algılanır ve düzeyleri ne durumdadır?" sorusuna yanıt aranmaktadır. Böylece, avukatlık mesleğinde çalışma mutluluğunun ne düzeyde olduğu ve nasıl algılandığ 1 ile ilgili teoriye yeni bir kaynak, uygulama için ise; farkındalık kazandırılacağına inanılmaktadır.

\section{1. Örneklem}

Türkiye'de avukatların çalışma mutluluğunu ölçen, gözünden değerlendiren bir çalışmanın olmayışı dikkat çekmektedir. $\mathrm{Bu}$ nedenle, örneklem sınırlılığında kolay ulaşılabilirlik özelliği de göz önünde bulundurularak, araştırmanın örneklemini işveren avukatlar, işçi avukatlar ve şirket avukatları oluşturmaktadır. 
İşveren avukat; taraflar arasında imzalanacak sözleşme ile verilmesi kararlaştırılan hizmetten yararlanan ve hizmet karşılığında ücret ödeme yükümlülüğü başta olmak üzere ilgili mevzuattaki diğer yükümlülükleri üstlenmiş avukat, avukatlık

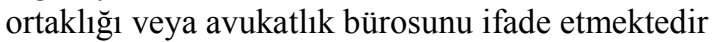
(https://www.barobirlik.org.tr/dosyalar/duyurular/2 0130924_yonerge.pdf, 08.04.2019). İşçi avukat, başka bir avukatın yanında aylık ücretli çalışan avukattır (Gürseler, 2006). Şirket avukatı ise; anonim limited ve sermayesi paylara bölünmüş komandit şirketlere hukuki destek sunan ve danışmanlık hizmeti veren hukukçudur (https://www.proaktifhukuk.com/sirketavukati.html, 08.04.2019).

Araştırmanın evrenini Türkiye'de en az 1000 avukatın kayıtlı olduğu ve fiilen en az 6 aydır çalışan işveren ve işçi avukatlar ile şirket avukatları oluşturmaktadır. Söz konusu avukatlara 1200 soru formu dağıtılarak, 172 adet geri dönüş sağlanmış ve 168 geçerli yanıt elde edilmiştir. Örnekleme yöntemi olarak nicel araştırma kısmı için kolayda örnekleme (Bhattacherjee, 2012), nitel araştırma kısmı için maksimum çeşitlilik örneklemesi (Patton, 1990) tercih edilmiştir.

Örneklemin 93'ünü (\% 53,8) kadın; 75'ni $(\%$ 43,4) erkek avukat oluşturmaktadır. Avukatların 105 'i (\% 62,9) evli; 62'i (\% 37,1) bekâr olduğunu belirtmiştir. Çalışma biçimine göre dağılım işveren avukat 89 (\% 53,0); işçi avukat avukat $31(\%$ 18,5) ve şirket avukatı $48 \quad\left(\begin{array}{lll}\% & 28,6) & \text { şeklindedir. }\end{array}\right.$ Örneklemin yaş gruplarına göre dağılımı Levinson'un (Levinson, 1986) geliştirmiş olduğu kariyer yaş modeline göre sınıflanmıştır. Buna göre; avukatların yaş dağılımı şu şekildedir: 51'i $(\% 30,4)$ 23-29; 13 'ü (\% 7,7) 30 - 32; 21 'i (\% 12,5) 33 - 39; 14'ü (\% 8,3) 40-43; 19'u \% 8,3 40-43; 19'i (\% $11,3)$ 44-50 yaş aralığında ve 50'si (\% 29,8) 51 yaş üzerindedir. 144 (\% 85,7) avukat lisans; 24 (\%14,3) avukat ise, yüksek lisans öğrenimini tamamladığını belirtmiştir. Avukatların 17'i (\% 10,1) 1 yıldan az; 37'si (\% 22,0) 1-5; 26'si (\% 15,5) 6-10; 23 'ü (\% $13,7) 11-15 ; 15$ 'i $(\% 8,9)$ 16-20; 10 'u $(\% 6,0)$ 21-25 yıl arası ve 40'1 (\% 23,8) 26 yıldan daha fazladır özel sektörde avukatlık yapmaktadır.

\subsection{Araştırmanın Yöntemi}

Araştırmanın yöntemi, nitel ve nicel araştırma yönteminin birlikte kullanıldığ 1 karma yöntem araştırmasıdır (Gunnell, 2016). İnsanların çevresindeki olay ve olguların karmaşık ve çok boyutlu bir yapıya sahiptir ve bunları algılamak, anlamak ve açıklamak zor olabilmektedir. $\mathrm{Bu}$ nedenle, karma yöntem özellikle psikoloji (Campbell \& Fiske, 1959), sosyal bilimler (Tashakkori \& Teddlie, 2010) ve insan kaynakları yönetimi (Onwuegbuzie \& Johnson, 2004) için kullanılabilecek yararlı bir araştırma yöntemi olarak önerilmiş, özellikle sosyal bilimlerde bir problem/olay/olguyu anlayabilmek için farklı yöntemlerin bir arada kullanılması gerektiği savunulmuştur (Mason, 2006). Araştırmanın deseni çeşitleme desenidir ve bu desende nicel ve nitel yöntemler aynı anda birlikte kullanılarak, elde edilen verileri çeşitlendirme, karşılaştırma, bütünleştirme ve araştırma soruları ile doğrudan ilgili veriler elde etme hedeflenir (Morse, 2003). Sosyal bilimler bağlamında çalışma mutluluğunun çok boyutlu, karmaşık ve göreceli bir içeriğe sahipliği, henüz yeni bir araştırma konusu olması gibi nedenlerle tanımlanmasının, açıklanmasının, anlaşılmasının ve algılanmasının karmaşık ve güç olduğu düşünülmektedir. Bu nedenle karma yöntem araştırmasının bu makale için uygun bir araştırma yöntemi olduğu öngörülmüştür. Göreceli bir yapıya sahip olan çalışma mutluluğuna ilişkin veri çeşitliliği ve bütünlüğü sağlayabilmek için de çeşitleme deseni tercih edilmiştir.

\subsection{Veri Toplama Araçları}

Nicel araştırma verileri, çalışma mutluluğu düzeyinin belirlenmesi, demografik değişkenlere göre karşılaştırmalarının yapılabilmesi için nicel araştırma kısmı için Paschoal ve Tamayo (2008) tarafindan geliştirilen, Arslan ve Polat (2017) tarafından Türkçe'ye uyarlanan "Çalışma Mutluluğu" ölçeği ile toplanmıştır. Ölçek olumlu duygular (9 ifade), olumsuz duygular (12 ifade) ve içsel doygunluğun verdiği mutluluk (8 ifade) olmak üzere üç alt boyutta 29 maddeden oluşmaktadır. Ölçümü 5'li likert türünde yapılmıştır. Ölçeğe ilişkin Cronbach alpha katsayıları genel çalışma mutluluğu: .739; olumlu duygular: .932; olumsuz duygular: .937 ve içsel doygunluğun verdiği mutluluk: .881 olarak bulunmuştur. Cronbach alpha sayısının genel olarak .70'den büyük değer alması gerekmektedir (Özdemir, 2010). Bu noktada, kullanılan ölçeğin güvenirlik değeri kabul gören aralıklardadır. Çalışma mutluluğunu alt boyutları olarak olumlu duygular; çalışma yaşamında kişiye keyif veren duyguları deneyimlemeyi ve olumlu bir ruh hali içinde olmayı, zevk, heyecan, neşe ve huzur gibi duyguları (Warr, 2007); olumsuz duygular kişinin keyif almadığı ya da hoş olmayan duyguları deneyimlemeyi, huzursuzluk, gerginlik, agrasiflik, endişe gibi duyguları içerir (Diener, 2000). İçsel doygunluğun verdiği mutluluk boyutu ise; çalışma mutluluğunun bilişsel yönünü yansıtır. Kişisel niteliklerin geliştirilmesi, iş ve kişi uyumu, potansiyelin keşfi ve gerçekleşmesi gibi unsurlardan oluşur (Warr, 2007). 
Nitel araştırma verileri ise; özel sektör avukatları için çalışma mutluluğunun ne ifade ettiği ve onlar tarafından nasıl algılandığını ortaya çıkarmak için, "Sizin için çalışma mutluluğu ne ifade etmektedir?" şeklinde tek bir soru ile toplanmıştır. Araştırmalarda soru sayısının az olmasının araştırma sorularının kolay cevaplanmasını sağlayacăğ, katılımı artıracağı, zaman ve zamana bağlı konsantrasyon durumları göz önünde bulundurulduğunda daha fazla verim alınacağ 1 (Keser, 2018) sebebiyle nitel kısımda tek bir soru tercih edilmiştir. Böylece, avukatların iş yoğunluğu oldukça yüksek bir meslek grubu olmasından dolayı en kısa araştırma formu oluşturulmaya gayret edilmiş ve bu sayede düşüncelerini net, açık, kolayca ve tarafsız ortaya koyabilecekleri düşünülmüştür. Ayrıca, nitel araştırma sorusu ile ilgili bir alt sınır verilmemiştir. Bir araștırmanın, belirli bir soru veya soruların sistematik ve mantıklı bir biçimde cevaplandırılmasına yönelik bir çaba olduğu ve bu nedenle, araştırmaya yön veren soru veya soruları cevaplayabilecek bilgiler toplandığ 1 , yorumlandığ 1 ve sonuçlandığı (Yıldırım, 1999) belirtilmektedir.

Nitel veriler önce kodlanmıș, ardından kodlanan verilerinin temaları belirlenmiş, kodlar ve temalar düzenlenmiştir. Ayrıca, bu temalar kelime ve cümle düzeyinde ele alınmış, bunları desteklemek için de niteliğinde doğrudan alıntılama yönteminden faydalanılmıştır. Son olarak bulgular tanımlanmış ve yorumlanmıştır. $\mathrm{Bu}$ süreçte elde edilen nitel veriler bir Word dosyasina aktarılarak araştırmacının kendisi tarafindan ikişer gün aralıklarla dört kez okunmuş ve her bir okumada kodlamalar oluşturulmuştur. Ardından bu kodlamalar bir araya getirilerek temalar ortaya çıkarılmıştır. İçerik analizi için, güvenirliğin belirlenmesi amaciyla (Miles \& Huberman, 1994) kodlayıcılar arası tutarlılık hesaplanması için, oluşturulan görüşme kodlama anahtarları araştırmacının dışında alana hakim üç araştırmacıya verilmiş ve bunlar araştırmacılar tarafindan okunmuş, kodlanmıştır. Daha sonra bu üç araştırmacının kodlamaları karşılaştırılmıştır. Kodlama güvenirliği \%79,9 bulunmuştur.

\subsection{Verilerin Toplanması}

Araştırmaya ilişkin veriler, 2018 Ekim - 2019 Ocak arasında çevrimiçi olarak hazırlanan bir anket formu aracılığı ile toplanmıştır. Bu anket formunda, yapılan araştırmanın bilimsel bir amaçla yapıldığı ve verilerin yalnızca bilimsel amaçlar için kullanılacağı, katılımcı kimliklerinin açıklanmayacağı belirtilmiş, araştırmanın amacı ile içeriği hakkında kısa bir bilgiye yer verilmiştir. Ardından, katılımcılar ile e-posta ve telefon mesajı aracılığıyla paylaşılmıştır.

\subsection{Verilerin Analizi}

Nicel verilerin analizinde betimsel istatistik, nitel verilerin analizinde toplanan verileri açılayabileyecek kavramlara ulaşmak, temalar oluşturmak için içerik analizi yapılmıştır. İçerik analizinden elde edilen bu verileri yorumlayabilmek için de doğrudan alıntılanmalara yer verilmiștir. Ardından, iki analizden elde edilen sonuçlar karşılaştırılmış ve birlikte yorumlanmıştır.

Nicel Bulgular. Örneklemin genel çalışma mutluluğu ile alt boyutlarına ilişkin 5'li likert ölçeğine göre aritmetik ortalamalar Tablo 1'de yer almaktadır. Elde edilen bulgulara göre; avukatların genel çalışma mutluluğunun 3,07 ; olumlu duygularının 3,16; olumsuz duyguların 2,58 ve içsel doygunluğun verdiği mutluluğunun 3,71 düzeyinde olduğu görülmektedir. $\mathrm{Bu}$ bulgular 5'li likert ölçeğine göre aritmetik ortalamaların değerlendirme aralığında (Kaplanoğlu, 2014: 138) genel çalışma mutluluğu "yeterince" ifadesine karşılık gelen 2,613,40 aralığında ortalama; içsel doygunluğun verdiği mutluluk "katıllyorum"a karşıl1k gelen 3,41-4,20 aralığında yüksek düzeydedir. Daha önce yapılmış araştırmalarda da benzer ortalamalar ortaya çıkmıştır (Nam \& Kwon, 2013; Erselcan \& Süral Özer, 2018). Bir başka araştırma sonucunda ise; çalışma mutluluğu "kesinlikle katılıyorum"a karşılık gelen 3.51 olarak oldukça yüksek düzeyde çıkmıştır (Bataineh, 2019).

Cinsiyet, medeni durum ve eğitim durumuna göre anlamlı bir farklılık olup olmadığını analiz etmek için Bağımsız Örneklem T Testi; çalışma biçimine göre farklılık olup olmadığını analiz etmek için Tek Yönlü Varyans Analizi (ANOVA) Post-Hoc Tukey kullanılmıştır. Tablo 2'de yer alan bulgular incelendiğinde erkeklere göre kadınların genel çalışma mutluluğu, olumlu duygular ve içsel doygunluğun verdiği mutluluk ortalamalarının daha

Tablo 1: Avukatların Genel Çalışma Mutluluğu ve Boyutlarının Ortalamaları

\begin{tabular}{lc}
\hline Olumlu Duygular & 3,16 \\
\hline Olumsuz Duygular & 2,58 \\
İçsel Doygunluğun Verdiği Mutluluk & 3,71 \\
Genel Çalışma Mutluluğu & 3,07 \\
\hline
\end{tabular}


yüksek; olumsuz duygularının daha düşük olduğu görülmektedir. Cinsiyete göre mutluluğun değişip değişmediği pek çok çalışmada ele alınmaktadır. Yapılan bir araştırma sonucu, kadınların, erkeklerden önemli ölçüde daha fazla mutsuz olduklarını ortaya koymuştur ve sebebi zaman kısıtlaması olarak ortaya konulmuştur (Milhouse, 2005). Bir başka araştırmada daha, erkeklerin çalışma mutluluğunun kadınlardan daha yüksek olduğu sonucunu vermiştir (Adelman, 1987). Tüm bu sonuçların yanında, literatürde bu konuda, belirsizlikler ve tutarsızlıklar olduğu öne sürülmektedir (Arthur, 1987). Bu nedenle, cinsiyet bağlamında çalışma mutluluğu düzeyine ilişkin daha kapsamlı çalışmalar yapılabilir.

Medeni duruma göre; evli avukatların genel çalışma mutluluğu, içsel doygunluğun verdiği mutlulukları ve olumlu duyguları bekâr avukatlara göre daha düşük; olumsuz duyguları ise, evli ve bekâr avukatlar için eşit düzeyde çıkmıştır.

Eğitim durumuna göre olumlu duygular ile içsel doygunluğun verdiği mutluluğun lisans mezunları için yüksek lisanslara göre daha yüksek; olumsuz duyguların daha düşük ortaya çıkmıştır. Genel çalışma mutluluğu lisans ve yüksek lisans mezunları için birbirine oldukça yakındır, çok az bir farkla yüksek lisans mezunlarında daha yüksek olduğu görülmektedir. Böylece avukatların eğitim düzeyindeki artışa göre olumlu duygular ile içsel doygunluğun verdiği mutluluğun düştüğü söylenebilir. Benzer biçimde, Hindistan'da yapılan bir araştırmada eğitim düzeyi yükseldikçe çalışma mutluluğu ortalamalarının düștüğü sonucu ortaya çıkmıştır (Khanna \& Singh, 2018). Öte yandan, çalışma biçimlerine göre genel çalışma mutluluğu ile içsel doygunluğun verdiği mutluluk ortalamasının en yüksek işveren avukatlar, en düşük şirket avukatları arasında; olumlu duygular ile olumsuz duygular ortalamasının en yüksek şirket avukatları arasında olduğu görülmektedir.

Yapılan Tek Yönlü Varyans Analizine (ANOVA) göre; genel çalışma mutluluğu ile alt boyutlarının cinsiyete, medeni duruma ve eğitim düzeyine göre anlamlı bir farklılık göstermediği sonucuna varılmıştır. Örneğin, Bangladeş’te yapılan bir araştırmada çalışma mutluluğunun cinsiyete göre anlamlı bir farklılık göstermediği; kadın ve erkek çalışanların ortalama olarak mutlu oldukları ortaya çıkmışıı (Tahlil Azim, Haque \& Chowdhury, 2013). Bir başka araştırmada ise; kadınların erkeklerden daha fazla çalışma mutluluğuna sahip olduğu sonucu elde edilmiştir (Poopanit, 2008). Ancak, bazı araştırmalarda çalışma mutluluğunun cinsiyetle bir bağının olmadığı, duygu deneyimlerinin farklılık göstermediği ve duygu ifadelerinin yalnızca statüleriyle bağlantılı olduğu öne sürülmekte, kadınların çalışma ortamında mutluluk ya da öfke gibi duygularını erkeklerden daha az ifade ettikleri savunulmaktadır (Sloan, 2012). Savunulan bir başka görüş ise; çalışma mutluluğunun cinsiyete göre anlamlı farklılık gösterip göstermediğine ilişkin ayrımlara esasında cinsiyet ve duygu hakkındaki basmakalıp inançların neden olduğu; bu farklılığın yalnızca kadın ve erkeğin çalıştı̆̆ farklı koşullarla ilgili olduğudur (Jennings ve Greenberg 2009). Bir başka açıdan, çalışma mutluluğu bağlamında avukatlar arasında yapılan bir araştırma sonucu, avukat olarak çalışma yaşamına adım atmak, kariyer yapmak isteyen ve bunun için işe alınma ve bundan mutlu olma hissinin kadın avukatlar arasında daha 1lımlı algılanan bir konu olduğunu göstermiştir (Semaan, 2018). Örneğin, "Mutlu Avukat: Hukukta İyi

Tablo 2: Cinsiyet, Medeni Durum, Eğitim Durumu ve Çalışma Biçimine Göre Çalışma Mutluluğu ve Alt

Boyutları Ortalaması

\begin{tabular}{|c|c|c|c|c|c|c|c|c|c|}
\hline \multirow[b]{2}{*}{$\begin{array}{l}\text { Çalışma } \\
\text { Mutluluğu } \\
\text { ve Boyutları }\end{array}$} & \multicolumn{2}{|c|}{ Cinsiyet } & \multicolumn{2}{|l|}{$\begin{array}{l}\text { Medeni } \\
\text { Durum }\end{array}$} & \multicolumn{2}{|c|}{ Eğitim Durumu } & \multicolumn{3}{|c|}{ Çalışma Biçimi } \\
\hline & $\begin{array}{l}\text { Kadın } \\
\mathrm{N}=93\end{array}$ & $\begin{array}{l}\text { Erkek } \\
N=75\end{array}$ & $\begin{array}{l}\text { Evli } \\
\mathrm{N}=105\end{array}$ & $\begin{array}{l}\text { Bekâr } \\
\mathrm{N}=62\end{array}$ & $\begin{array}{l}\text { Lisans } \\
\mathrm{N}=23\end{array}$ & $\begin{array}{l}\text { Yüksek } \\
\text { Lisans } \\
\mathrm{N}=144\end{array}$ & $\begin{array}{l}\text { İşveren } \\
\text { Avukat } \\
\mathrm{N}=31\end{array}$ & $\begin{array}{l}\text { İşçi } \\
\text { Avukat } \\
\mathrm{N}=89\end{array}$ & $\begin{array}{l}\text { Şirket } \\
\text { Avukatı } \\
\mathrm{N}=48\end{array}$ \\
\hline Olumlu Duygular & 3,22 & 3,08 & 3,12 & 3,24 & 3,18 & 3,03 & 3,03 & 3,06 & 3,43 \\
\hline Olumsuz Duygular & 2,57 & 2,62 & 2,60 & 2,59 & 2,57 & 2,73 & 2,70 & 2,15 & 2,96 \\
\hline $\begin{array}{l}\text { İçsel Doygunluğun } \\
\text { Verdiği Mutluluk }\end{array}$ & 3,78 & 3,61 & 3,63 & 3,83 & 3,72 & 3,53 & 3,74 & 3,55 & 3,72 \\
\hline $\begin{array}{l}\text { Genel Çalışma } \\
\text { Mutluluğu }\end{array}$ & 3,10 & 3,04 & 3,04 & 3,14 & 3,07 & 3,08 & 3,10 & 3,14 & 2,98 \\
\hline
\end{tabular}


Yaşamı Başarmak" isimli bir kitap, avukatlara çalışma yaşamlarında orta vadeli mutluluk elde etmelerine yönelik kariyerleri ile ilgili pratik araçlar sunar (Levit \& Linder, 2010). Cinsiyetin yanı sıra, medeni duruma göre çalışma mutluluğunun anlamlı farklılık göstermediğini (Ongkana, 2006; Tahlil Azim vd., 2013) ve gösterdiğini ortaya çıkaran çalışmalar da (Nam \& Kwon, 2013) vardır.

Çalışma biçimleri için yapılan Tek Yönlü Varyans Analizi (ANOVA) çalışma mutluluğunun çalışma biçimlerine göre yalnızca olumsuz duygular açısından anlamlı bir farklılık gösterdiği sonucunu vermiştir. Elde edilen bulgulara göre; işveren avukatlar ile işçi avukatlar ve şirket avukatları arasında olumsuz duygular açısından anlamlı bir farklılık ( $p=, 002 \mathrm{p}=, 000)$ görülmektedir. İșveren avukatlar ile işçi avukatların şirket avukatlarına göre olumsuz duygularının daha yüksek olduğu söylenebilir. Bunun yanında, avukatlarla yapılmış bir araştırma sonucunda, işçi avukatların \% 60' ının çalışmadan mutsuz oldukları ve esnek çalışmadan memnun olmadikları; \% 66' inın ise ücret düzeyinden memnun olmadıkları, genel olarak da çalışmada mutsuz oldukları ortaya çıkmıştır (Barlow \& Brooks, 2018).
Çalışma mutluluğu ve alt boyutlarının yaşa göre anlamlı bir farklılığının olup olmadığını analiz etmek için yapılan Tek Yönlü Varyans Analizi (ANOVA) yapılmıştır. Yaş ortalamasına göre genel çalışma mutluluğu için en yüksek ortalamanın 2329 yaş, olumlu duygular için 44-50 yaş, içsel çalışma mutluluğu için 23-29 yaş arasındaki avukatlara ait olduğu görülmektedir. Olumsuz duygular açısından en yüksek ortalama 33-39 yaş arasındaki avukatlara aittir. Bulgular çalışma mutluluğunun yaşa göre yalnızca olumsuz duygular ile genel çalışma mutluluğu açısından anlamlı farklılık gösterdiği sonucunu vermiştir. Sonuçlara göre 23-29 yaş arasındaki avukatlar ile 51 yaş ve üzerindeki avukatlar arasinda olumsuz duygular açısından $(\mathrm{P}=, 048)$; genel çalışma mutluluğu açısından 30-32 yaş arasındaki avukatlar ile 51 yaş ve üzerindeki avukatlar arasında anlamlı bir farklılık olduğu $(\mathrm{P}=, 006)$ görülmektedir. Ancak, olumlu duygular ve içsel doygunluğun verdiği mutluluk açısından yaşa göre anlamlı farklılık ortaya çıkmamıştır. Bulgulardan genel olarak çıkarılabilecek sonuç 51 yaş ve üzeri avukatların 23-29 yaş ve 30-32 yaş arasındaki avukatlara göre daha düşük çalışma mutluluğuna sahip olduğudur. Buna göre 23-29 yaş arasındaki avukatların 51 yaş ve üzerindeki avukatlara göre olumsuz duygularının daha düşük olduğu söylenebilir. $\mathrm{Bu}$ sonuçları

Tablo 3: Çalışma Biçimine Göre Tek Yönlü Varyans Analizi (ANOVA) Sonuçları

\begin{tabular}{|c|c|c|c|c|c|}
\hline $\begin{array}{l}\text { Bağımlı } \\
\text { Değişken }\end{array}$ & $\begin{array}{l}\text { Çalışma } \\
\text { Biçimi (I) }\end{array}$ & $\begin{array}{c}\text { Çalışma Biçimi } \\
(\mathbf{J})\end{array}$ & $\begin{array}{c}\text { Ortalama Fark } \\
\text { (I-J) }\end{array}$ & $\begin{array}{r}\text { Standart } \\
\text { Sapma }\end{array}$ & $\mathbf{P}$ \\
\hline \multirow{6}{*}{$\begin{array}{l}\text { Olumsuz } \\
\text { Duygular }\end{array}$} & İşveren Avukat & İşçi Avukat &,- 256 & ,188 & ,365 \\
\hline & & Şirket Avukatı &, $552^{*}$ & ,162 &, 002 \\
\hline & İşçi avukat & İşveren Avukat & ,256 & ,188 & ,365 \\
\hline & & Şirket Avukatı &, $\mathbf{8 0 8 *}$ & ,208 & ,000 \\
\hline & Şirket Avukatı & İşveren Avukat &,$- 552^{*}$ & ,162 &, 002 \\
\hline & & İşçi Avukat &,$- 808^{*}$ & ,208 &, 000 \\
\hline
\end{tabular}

Not. $* 0.05$ düzeyinde anlamlı farklılık vardır.

Tablo 4: Yaşa Göre Çalışma Mutluluğu ve Alt Boyutları Ortalaması

\begin{tabular}{|c|c|c|c|c|c|c|}
\hline $\begin{array}{l}\text { Çalışma Mutluluğu ve } \\
\text { Alt Boyutları }\end{array}$ & $\begin{array}{l}23-29 \text { yaş } \\
\text { arası }\end{array}$ & $\begin{array}{l}30-32 \text { yaş } \\
\text { arası }\end{array}$ & $\begin{array}{l}33 \text { - } 39 \text { yaş } \\
\text { arası }\end{array}$ & $\begin{array}{l}40-43 \text { yaş } \\
\text { arası }\end{array}$ & $\begin{array}{l}44-50 \text { yaş } \\
\text { arası }\end{array}$ & $\begin{array}{l}51 \text { yaş ve } \\
\text { üzeri }\end{array}$ \\
\hline Olumlu Duygular & 3,25 & 2,62 & 3,17 & 2,79 & 3,39 & 3,21 \\
\hline Olumsuz Duygular & 2,77 & 3,26 & 2,63 & 2,70 & 2,43 & 2,24 \\
\hline $\begin{array}{l}\text { İçsel Doygunluğun } \\
\text { Verdiği Mutluluk }\end{array}$ & 3,84 & 3,61 & 3,71 & 3,74 & 3,53 & 3,64 \\
\hline Genel Çalışma Mutluluğu & 3,22 & 3,02 & 3,10 & 3,16 & 2,93 & 3,01 \\
\hline
\end{tabular}


Tablo 5: Yaşa göre Tek Yönlü Varyans Analizi (ANOVA) Sonuçları

\begin{tabular}{|c|c|c|c|c|c|}
\hline $\begin{array}{l}\text { Bağımlı } \\
\text { Değiş̧ken }\end{array}$ & Yaş (I) & Yaş (J) & $\begin{array}{l}\text { Ortalama } \\
\text { Fark (I-J) }\end{array}$ & $\begin{array}{l}\text { Standart } \\
\text { Sapma }\end{array}$ & $\mathbf{P}$ \\
\hline \multirow{15}{*}{$\begin{array}{c}\text { Olumsuz } \\
\text { Duygular }\end{array}$} & \multirow[t]{5}{*}{$23-29$ yaş arası } & 30 - 32 yaş arası &,- 493 &, 283 & ,507 \\
\hline & & 33 - 39 yaş arası &, 135 &, 236 & ,993 \\
\hline & & $40-43$ yaş arası & ,067 &, 275 & 1,000 \\
\hline & & 44 - 50 yaş arası &, 335 &, 245 & ,746 \\
\hline & & 51 yaş ve üzeri &, $526 *$ & ,181 & ,048 \\
\hline & \multirow{5}{*}{$\begin{array}{l}30 \text { - } 32 \text { yaş } \\
\text { arası }\end{array}$} & $23-29$ yaş arası & ,493 &, 283 &, 507 \\
\hline & & 33 - 39 yaş arası & 628 & ,322 & ,375 \\
\hline & & $40-43$ yaş arası &, 560 &, 351 & ,602 \\
\hline & & 44 - 50 yaş arası & 829 & ,328 &, 123 \\
\hline & & 51 yaş ve üzeri & $1,019^{*}$ & ,284 & ,006 \\
\hline & \multirow[t]{5}{*}{51 yaş ve üzeri } & 23 -29 yaş arası &,$- 526^{*}$ & ,181 & ,048 \\
\hline & & 30 - 32 yaş arası & $-1,019^{*}$ & ,284 & ,006 \\
\hline & & 33 - 39 yaş arası &,- 392 &, 237 & ,566 \\
\hline & & $40-43$ yaş arası &,- 459 &, 276 &, 557 \\
\hline & & 44 - 50 yaş arası &,- 191 &, 246 & ,971 \\
\hline \multirow{10}{*}{$\begin{array}{l}\text { Genel Çalışma } \\
\text { Mutluluğu }\end{array}$} & \multirow[t]{5}{*}{23 -29 yaş arası } & 30 - 32 yaş arası &, 05654 &, 11671 & ,997 \\
\hline & & 33 - 39 yaş arası &, 11552 & ,09740 &, 843 \\
\hline & & $40-43$ yaş arası & ,20091 &, 11334 & ,486 \\
\hline & & 44 - 50 yaş arası & ,18412 & ,10096 & ,454 \\
\hline & & 51 yaş ve üzeri &, $28672^{*}$ &, 07476 & ,002 \\
\hline & \multirow[t]{5}{*}{51 yaş ve üzeri } & 23 -29 yaş arası &,$- 28672^{*}$ & ,07476 & ,002 \\
\hline & & 30 - 32 yaş arası &,- 23019 & ,11695 &, 365 \\
\hline & & 33 - 39 yaş arası &,- 17120 & ,09768 & ,499 \\
\hline & & $40-43$ yaş arası &,- 08581 &, 11358 & ,974 \\
\hline & & $44-50$ yaş arası &,- 10260 & ,10124 & ,913 \\
\hline
\end{tabular}

Not. *The mean difference is significant at the 0.05 level.

destekler nitelikte bir sonuç, Amerika'da avukatlar arasında yapılmış bir araştırmada da ortaya çıkmıştır. Bulgulara göre; 38-58 yaş arasındaki avukatların daha mutsuz olduğu sonucuna varılmıştır (Barlow \& Brooks, 2018). Ancak, hukuk dünyası yakın zamana kadar mutluluk çalışmalarına fazla odaklanmadığı için (Wolfrum, 2010) bu konuda avukatlar üzerine yeterli çalışmanın olmadığı dikkat çekmektedir. Gelecek araştırmalarda benzer ya da farklı sonuçlar ortaya çıkabilir. Örneğin, yapılan araştırmalarda öğretmenler arasında yaş ortalaması yükseldikçe çalışma mutluluğunun artış gösterdiği (Tan \& Majid, 2011); 20-34 yaş aralığındaki rektörlük personelinin 35-49 yaş aralığındaki personele göre çalışma mutluluklarının daha yüksek olduğu ortaya 
çıkmıştır (Poopanit, 2008). Bu bulgulardan çıkarılabilecek genel sonuç avukatlar arasında çalışma mutluluğu araştırmalarının yaygınlık kazandırılarak veri zenginliği sağlanmasına yönelik çalışmaların yapılması gerektiğidir.

Nitel Bulgular. Araştırmanın literatür kısmında çalışma mutluluğunun, çalışma ortamında olumlu duyguların yaşanma sıklığı, farkına varılma durumu ile bu duyguların artırılmasına yönelik girişimlerin ya da olumsuz duyguların varlığı ile yüzleşme, farkına varma ve bunları olumlu duygulara doğru çekebilmenin toplam sonucu olduğuna yönelik çıkarımlar yapılmıştı. Bunun yanında, araştırmanın nicel analiz kısmında kullanılan ölçekteki ifade ve alt boyutların olumlu ve olumsuz duygular ile içsel doygunluğun verdiği mutluluk olduğu belirtilmişti. $\mathrm{Bu}$ verilerden hareketle, "Çalışma mutluluğu sizin için ne ifade etmektedir?" sorusuna verilen yanttlar "olumlu duygu ve düşüncelerin yaygın olarak varlığ1 (80 kavram)", "olumsuz duygu ve düşüncelerin farkında olma/farkına varma (13 kavram)" ile "içsel doygunluğun verdiği mutluluk (91 ifade)" ana temaları altında incelenmiştir. Bunun yanında, çalışma ortamı koşulları (54 ifade) ile para, ücret, gelir (17 ifade) temaları da ortaya çıkmıştır.

\section{Tema 1: Olumlu duygu ve düşüncelerin yaygın olarak varlı̆̆ı.}

Çalışma mutluluğu, her zaman gülümsemek, pozitif düşünmek ve sürekli neşeli bir ruh halinde olmak değildir (Pryce-Jones, 2010). Çalışma ortamında pozitif duyguların yaygınlığı (Paschoal \& Tamayo, 2008) ve pozitif duygulanım ile olumlu tutumları etkileyen bir yapıdır (Fisher, 2010). Bunun yanında, olumlu duygular çalışanların çalışma ortamında beklenen verimliliği için önemli konular arasındadır (Golparvara \& Abedini, 2014). Avukatlardan bazılarının çalışma mutluluğu bağlamında olumlu duygu ve düşüncelerin yaygın olarak varlığına ilişkin görüşleri aşağıdaki gibidir:

..."Çevrede duyulan sevgi ve saygının zamanla artmas1, mutluluğun ta kendisidir.'K5, "İşyerinde geçen zamanın, her zaman olmasa da keyifli ve verimli geçmesi."K41, "Hayattan daha çok keyif almamı sağlayan durumu; mutsuzluğumu azaltan, mutluluğumu arttıran hissi ifade eder."K66, "Bence huzurlu yaşamdır."K50, "Manevi tatmin ve huzur."K53, "Huzurlu bir meşgale." K55, "Huzur ve güven". K76, "Mutlu olmayı ifade ediyor, huzur bulmam". K84, "Huzurlu bir ortamda başarılı olmak ve bunun maddi karşılığını almak". K94, "Neşe."K118, “Akşam eve mutlu ve keyifli gidebilmek ve yarını iple çekmektir." K91, "İşinden keyif almayı". K104, "Liyakat ve

Tablo 6: Ana Temalara Göre Belirtilen Kavram ve İfade Sıklıkları

\begin{tabular}{|c|c|c|c|c|c|}
\hline $\begin{array}{l}\text { Olumlu duygu ve } \\
\text { düşüncelerin } \\
\text { yaygın olarak } \\
\text { varlığı }\end{array}$ & $\begin{array}{l}\text { Kavram } \\
\text { Sıklığı }\end{array}$ & $\begin{array}{l}\text { Olumsuz duygu ve } \\
\text { düşüncelerin } \\
\text { farkında } \\
\text { olma/farkına varma }\end{array}$ & $\begin{array}{l}\text { Kavram/İfade } \\
\text { Sıklığı }\end{array}$ & $\begin{array}{l}\text { İcsel } \\
\text { Doygunluğun } \\
\text { Verdiği Mutluluk }\end{array}$ & $\begin{array}{l}\text { İfade } \\
\text { Sıklığı }\end{array}$ \\
\hline Huzur & 43 & Mutsuzluk & 4 & İşi severek yapma & 24 \\
\hline Mutluluk & 18 & Üzüntü & 2 & $\begin{array}{l}\text { Potansiyeli } \\
\text { gerçekleştirme }\end{array}$ & 49 \\
\hline Keyif & 6 & Korku & 1 & Beceri geliştirme & 13 \\
\hline Neșe & 1 & Stres & 1 & $\begin{array}{l}\text { Beceri- faaliyet } \\
\text { uyumu }\end{array}$ & 5 \\
\hline Güven & 6 & $\begin{array}{l}\text { Yaşamın kendisi ve } \\
\text { tüm duygular }\end{array}$ & 5 & $\underline{\text { Toplam }}$ & $\underline{91}$ \\
\hline Sevgi ve sayg1 & 6 & $\underline{\text { Toplam }}$ & $\underline{13}$ & & \\
\hline Toplam & $\underline{80}$ & & & & \\
\hline \multicolumn{6}{|c|}{ Diğer } \\
\hline Para, ücret, gelir & & & & & 17 \\
\hline \multicolumn{5}{|c|}{ Çalıșma ortamı koşulları } & 54 \\
\hline
\end{tabular}


bilgiye önem, değer verilecek bir çalışma ortamı, sevgi ve iletişimin olduğu, karşılıklı saygı ile işlerin yürütüldüğü bir ortamda mesleki çalışma beni mutlu eder". K146, "Severek, zevk alarak maximum verimli çalışma ve karşılığında maddi ve manevi hazzını alarak üretmenin mutluluğunu yaşayabilmektir.” K93...

Olumlu duygular çalışma yaşamında kişiye keyif veren duyguları deneyimlemeyi ve olumlu bir ruh hali içinde olmayı, heyecan, neşe, umut, ilham (https://positivepsychologyprogram.com/positiveemotions-list-examples-definitionpsychology/\#definition-positive-emotions, 03.04.2019), keyif, mutluluk hoşnutluk durumlarını içerir (Andrie, 2011) ve olumlu duygular mutluluğun yüksek düzeyini gösterir (Warr, 2007). Katılımcıların yukarıdaki ifadelerinde mutluluk, keyif ve sevgi gibi olumlu duyguları dile getirdikleri, en fazla ise huzur ifadesini kullandıkları görülmektedir.

\section{Tema 2: Olumsuz duygu ve düşüncelerin farkında olma/farkina varma.}

Mutluluk tüm insani duyguların harmanlanmasindan, olumlu olumsuz duyguların dengesinden ortaya çıkan bir duygu durumudur. $\mathrm{Bu}$ noktada çalışma yaşamındaki mutluluğun var olabilmesi de olumlu ve olumsuz duyguların birlikte var olabilmesine bağlıdır. Bu durum çalışma mutluluğu tanımlarının bazılarında ele alınmıştır ve çalışanın tüm zamanını iyi duygularla geçirmesi ya da öfke, hayal kırıklığı, başarısızlık, çekememezlik gibi olumsuz duyguların olmaması değil, onun bu duygulardan mutluluğa geri gelmesini sağlayan farklı eylemler olarak ifade edilmiştir (Ersoy \& Ehtiyar, 2017). Başka bir ifadeyle bu denge, çalışma mutluluğunu oluşturan bir çatıdır. Avukatlardan bazılarını bu konudaki ifadeleri aşağıdaki gibidir:

..."Bazen mutlu bazen mutsuz."K59, "Mesleğinizde üst kademelere çıkabiliyor ise hitap ettiğiniz kesimde işe yarıyor ve insanlara faydası dokunuyorsa ve vicdanen rahatsam ve olumsuz bir takım durumlara baş edebiliyorsam çalışma mutluluğunu yakalamıştır."K80, "Sabah uyandığında işe giderken mutsuz olmamak benim için çalışma mutluluğu."K134, "İnsanın yalnızca hayatını idame ettirmek ve/veya başkaca bir alternatifi olmadığından yapmak zorunda bulunmadığ 1 aynı zamanda yaparken zevk alacağı bir işe sahip olmaktır."K64, "Çalışanların ve ortakların da aynı mutluluğu, aynı sıkıntıları, aynı üzüntüleri, aynı keyifleri paylaşmaları." K24, "Hayatınızın önemli bir kısmı çalışmakla geceginden hayatın yarısını ifade eder, ee hayatta hep gülerek, mutlu olarak geçmiyor ki, acı tatlı hayat dedikleri gibi işte". $\mathrm{K} 29 .$.

Olumsuz duygular, kişinin keyif almadığı ya da hoş olmayan duyguları deneyimlemeyi (Diener, 2000); üzüntü, öfke, kıskançlık, korku, suçluluk ve çaresizlik duygularını (Riggio, 2016) kapsar ve ayrıca olumsuz duygular mutluluğun düşük düzeyini gösterir (Warr, 2007). Örneğin, hekimler arasında yapılan bir araştırmada üzüntü ile çalışma mutluluğunun negatif yönde bir ilişkiye sahip olduğu ortaya çıkmıştır (Eckleberry-Hunt, Kirkpatrick, Taku, Hunt \& Vasappa, 2016). Başka bir ifadeyle, çalışma mutluluğunun var olabilmesi için olumsuz duyguların olumlu duygulara göre azlığ1 kabul edilir. Katılımcıların ifadelerinde olumsuz duyguların çok fazla bahsine yer verilmediği olumsuzlardan geriye kalan olumluları ifade ederek dolaylı olarak olumsuz duyguların farkında olduklarını belirtmişlerdir.

\section{Tema 3: İçsel doygunluğun verdiği mutluluk.}

İçsel doygunluğun verdiği mutluluk; çalışanın işini sevdiği, çalışma yaşamı kalitesini olumlu değerlendirdiği durum (Colombo \& Zito, 2014), önemli ölçüde iş yükünü yönetme konusunda çalışanın kendisinde algıladığı yetenek ile ilgilidir (Eckleberry-Hunt vd., 2016). Kişisel niteliklerin geliştirilmesi ve potansiyelin keşfi ve gerçekleşmesi gibi unsurlardan oluşur (Warr, 2007). Bu temaya ilişkin katılımcı ifadeleri aşağıdaki gibidir.

..."Çalı̧̧ıken potansiyelimi ortaya çıkaran; beni daha da ileri götüren ve toplumun menfaatlerine katk1 sağlayabilmek tarafımca çalışma mutluluğu olarak adledilmektedir."K53, "adaletin tecellisi için elimden geleni yaptım düşüncesi." K136, "Çalışmanın bir şey üretmenin veya bir hizmet vermenin ücret getirisini hesaba katmadan insanı tatmin etmesidir. İnsanın yaptığ 1 işi sevip sevmemesiyle doğrudan ilişkilidir.”K10, "İşimi severek yapmamın doğal sonucu."K152, "İşini severek yapma."K139, "Severek işini yapması ve karşılı̆̆ını alması."K144, "Sevdiğim işi yapmayı."K99, “İsleri eksiksiz yapmanın, becerimi sunmamın huzuru ve gelecek güvencesi sağlayacak çalışma imkânı olması."K4, "İşlerin altından kalkabilmek, başarı, azim, gayret, çaba ile potansiyelimi kullanabilme imkanım."K12, "Bir avukat mutlu olmazsa dosyalarına da gerekli özeni gösteremez, verimli olamaz; yani dosyaları yönetebilme becerisini de ifade eder."K23...

İçsel doygunluğun verdiği mutluluk, çalışma mutluluğunun bilişsel yönünü ifade eder (Warr, 2007). Katılımcılardan bazıları işi sevme, başarı ve gayret ile içsel doygunluklarını belirtmiştir. Öte yandan, işin anlamı ve başarı, stresin az olması ile 
birlikte çalışma mutluluğunu belirlemede önemli faktörlerdir (Eckleberry-Hunt vd., 2016). Ayrıca, kişisel başarı ve iş yükü yönetilebilirliği algısı ile çalışma mutluluğu arasında pozitif yönde anlamlı bir ilişki vardır (Fernández vd., 2017). İşyerindeki başarı, bazıları için yüksek bir yaşam standardından çok daha önemli bir mutluluk kaynağıdır (Lane, 1992). İçsel doygunluğun verdiği mutluluğun, olumlu ve olumsuz duygularla bağlantılı bir biçimde yüksek ya da düşük olduğu söylenebilir. Örneğin, bu konuda alt boyutlar arası ilişkinin yer aldığı çalışmalar yapılabilir.

Üç ana temanın yanı sıra, "para/ücret/gelir" ile "çalışma ortamı koşulları" da bazı avukatlar tarafindan çalışma mutluluğu olarak ifade edilmiștir. Paranın mutluluk getirip getirmeyece ği hemen hemen pek çok çalışmada ele alınsa da, bu konuda farklı sonuçlar ortaya çıkmaktadır. Örneğin, avukatlar ile yapılan bir araştırma sonucu çalışma mutluluğunu; özgürlük, uzmanlı ve insan ilişkilerinin; para, saygınlık ve statüden daha çok etkilediği ortaya koymuştur (Davis-Laack, 2017). Çalışma mutluluğunu "para/ücret/gelir" ile ifade eden bazı avukatların ifadeleri aşağıda yer almaktadır:

..."Helal para kazanmak.”K39, "Birilerinin hakkını yemeden para kazandığımı bilmek."K62, "Para kazanma.”K78, “iyi bir gelir."K160, "Emeğinin karşılığı olan ücreti almayı.”K49, Aldığın ücret ve yaptığın işin niteliğinin uyuşması."K60, "Maddi kazancımın iyi olmas1.”K26, “Çok para ile gelen mutluluk.”K28, "çalışmanın karşılığını maddi olarak almak."K59...

Katılımcıların yukarıdaki ifadelerinin, para ya da ücret ya da gelirin hak edilebilirliği üzerinde olduğu görülmektedir. Bunun yanında, araştırmalarda asgari düzeyde iyi bir gelirin ötesindeki gelirin ya da gelirdeki artışın mutluluğa çok az katkıda bulunduğunu, genellikle insanların fiili çalışma faaliyetlerinden boş zamana ya da eğlence faaliyetlerine göre daha fazla keyif aldığı ortaya çıkmıştır (Lane, 1992). Gelecek araştırmalarda yalnızca para gibi değişkenlerin yer aldığ çalışmaların daha açıklayıcı ve destekleyici olacağı söylenebilir; çünkü oldukça göreceli bir konu olan gelir ya da ücret ya da para-mutluluk ilişkisi detaylı incelenmelidir.

Çevresel koşullar (Salas-Vallina, Alegre \& Guerrero, 2018), elverişli bir çalışma ortamı ve altyapısı çalışanın iyilik hali ve mutluluğu üzerinde oldukça etkili bir faktördür (Sartori \& Catlaone, 2013). Bu koşullar çalışma saatleri, iş güvenliği, çalışma ortamındaki kişileri, fiziksel çalışma koşulları (Byrne, Chughtai, Flood \& Willis, 2012;
Martin, 2011) kapsar. Bu nedenle çalıșanların zamanlarının büyük çoğunu geçirdiği çalışma ortamı psikolojik ve fiziksel açıdan insancil olmalıdır (Andrew, 2011; Warr, 2007). Çalışma mutluluğunu çalışma ortamı koşulları ile ifade eden bazı avukatların görüşleri aşağıdaki gibidir:

...“Ortam ve düzen.’K119, “Çalışma ortamındaki bütünsel bir motivasyon getirisi olan denge."K111, “Değer verilecek bir çalışma ortamı.”K147, “İş arkadaşları ile huzurlu bir ortam ve düzen çalışma mutluluğuna katkı sağlayan en önemli unsurdur."K100, "İş arkadaşlarımla kardeş gibi olmak."K62, "Güler yüz tatlı dille, diyalog ile çözülemeyecek sorun olmadığını düşünenlerin olduğu ortam.” K130, "Sakinlik, rahatllk ve konforlu bir ortam."K3, "Temizlik, düzen çalışma arkadaşları."K9, "Ofis arkadaşlarımla olan uyum ve işbirliği, mesleki dayanışma.” K23...

Bir üniversitede 43 çalışan ile yapılan görüşmenin sonucu çalışanlar esnek çalışmanın onları "mutlu" yaptığını ve bu mutluluk ile isteğe bağlı davranış ve bir dizi performans sonucu arasında davranışsal bağlantılar olduğunu algıladıklarını göstermiştir (Atkinson \& Hall, 2011).

Nicel ve Nitel Bulguların Karşılaştırılması. Nitel araştırma verilerinin analiz edilmesinin ardından, ortaya çıkan ana temalar sıklıklarına göre bir kodlanmıştır. Buna göre dört ayrı durum açısından, bu durumları ifade eden avukatlar arasında çalışma mutluluğu ve alt boyutları ortalamaları yeniden alınmış; çalışma mutluluğu ile boyutlarının bu durumlara göre anlamlı farklılık gösterip göstermediği test edilmiştir. Çalışma mutluluğunu, gelir/ücret/para ile ifade eden avukatların; genel çalışma mutluluğu $(3,24)$ ile olumlu duygular $(3,89)$ ortalamalarının en yüksek olduğu görülmektedir. Literatürde var olan bulgulara göre; avukatlar için gelir/ücret/para bağlamında avukatların çalışma mutluluğuna yönelik genelleme yapılması mümkün değildir. Çünkü aldıkları ücreti/elde ettikleri geliri meslektaş olarak algıladıkları insanlarla karşılaştırılmaları çalışma mutluluk düzeyi ortaya çıkmaktadır (Levit, 2010). Kısaca, ücret/gelir/para faktörünün mutlak gelir ile göreceli gelir ayrımına göre ele alındığı söylenebilir. 
Tablo 7: Avukatların Çalışma Mutluluğu Algılarına Göre Çalıșma Mutluluğu ile Alt Boyutlarının Ortalaması

\begin{tabular}{|c|c|c|c|c|c|}
\hline $\begin{array}{l}\text { Çalışma Mutluluğu } \\
\text { ve Alt Boyutları }\end{array}$ & Huzur & $\begin{array}{c}\text { İşi } \\
\text { Severek } \\
\text { Yapma }\end{array}$ & $\begin{array}{c}\text { Potansiyelini } \\
\text { Gerçekleştirme }\end{array}$ & Gelir/ücret/para & $\begin{array}{c}\text { Çalışma Ortamı } \\
\text { Koşulları }\end{array}$ \\
\hline Olumlu Duygular & 3,30 & 3,10 & 2,70 & 3,89 & 3,24 \\
\hline Olumsuz Duygular & 2,46 & 2,73 & 2,89 & 2,43 & 2,28 \\
\hline $\begin{array}{l}\text { İçsel Doygunluğun } \\
\text { Verdiği Mutluluk }\end{array}$ & 3,75 & 3,69 & 3,40 & 3,73 & 3,76 \\
\hline $\begin{array}{l}\text { Genel Çalışma } \\
\text { Mutluluğu }\end{array}$ & 3,08 & 3,11 & 2,97 & 3,24 & 2,99 \\
\hline
\end{tabular}

Bunun yanında, çalışma ortamı koşullarının çalışma mutluluğunu ifade ettiğini belirten avukatlar arasında olumsuz duygular ortalamasının en düşük $(2,28)$, içsel doygunluğun verdiği mutluluğun ise; en yüksek $(3,76)$ olduğu dikkat çekmektedir. Bulgulara göre; çalışma mutluluğunu huzur ile ifade eden avukatlar ile potansiyeli gerçekleştirme olarak ifade eden avukatlar arasında olumlu duygulara göre anlamlı bir farklılık olmadığı görülmüştür. Buna göre; çalışma mutluluğunu potansiyeli gerçekleştirme olarak belirten avukatların, huzur olarak belirten avukatlara göre olumlu duygularının daha yüksek olduğu söylenebilir. Daha önce yapılmış bir araştırma sonucunda da, avukatların karamsarlıkları onları mutsuz eden faktörler olarak belirginlik kazanmıștır. Hatta bu durum, avukatların hayatlarının geri kalanına genellenmiştir. Bunun yanında, sağlık ve moral bozukluğunu teşvik eden, huzuru bozan koşullar olan yüksek baskı ve daha az katılımcı olma durumu, özellikle genç avukatların çalışma mutluluğunu olumsuz etkiler (Seligman vd., 2001). Öte yandan, insanlık doğal olarak huzur ve sakinlik isteyen iç ruha sahiptir. $\mathrm{Bu}$ nedenle avukatlar da huzur için dengeyi öğrenmeli ve huzurun mutluluğa olan katkısını göz önünde tutmalıdır (David, 2011).

İşi severek yapmayı, çalışma mutluluğu olarak ifade eden avukatlar ile huzur ve gelir, ücret ya da para olarak ifade eden avukatlar arasında da olumlu duygular açısından anlamlı bir farklılık vardır. Böylece, bu bulgular çalışma mutluluğunu huzur ve para/ücret/gelir ile ifade eden ya da algilayan avukatların işini severek yapma olarak ifade eden

Tablo 8: Çalışma Mutluluğu Algısına Göre Tek Yönlü Varyans Analizi (ANOVA) Sonuçları

\begin{tabular}{|c|c|c|c|c|}
\hline Bağımlı Değişken & $\begin{array}{l}\text { (I) } \\
\text { kavram/ifade }\end{array}$ & $\begin{array}{l}(\mathrm{J}) \\
\text { kavram/ifade }\end{array}$ & $\begin{array}{l}\text { Mean } \\
\text { Difference } \\
\text { (I-J) }\end{array}$ & Sig. \\
\hline \multirow{12}{*}{ Olumlu Duygular } & \multirow{3}{*}{ Huzur } & Potansiyeli gerçekleştirme & 0,413 & 0,965 \\
\hline & & İşi severek yapma & 0,008 & 1 \\
\hline & & Gelir/ücret/para & $-0,778$ & 0,801 \\
\hline & \multirow[t]{3}{*}{$\begin{array}{l}\text { Potansiyeli } \\
\text { gerçekleştirme }\end{array}$} & $\begin{array}{l}\text { Potansiyeli } \\
\text { gerçekleştirme }\end{array}$ &, $604 *$ & $\mathbf{0 , 0 3 7}$ \\
\hline & & Issi severek yapma & 0,199 & 0,943 \\
\hline & & Gelir/ücret/para & $-0,587$ & 0,521 \\
\hline & \multirow[t]{3}{*}{ İşi severek yapma } & Huzur &,$- 604 *$ & $\mathbf{0 , 0 3 7}$ \\
\hline & & İşi severek yapma & $-0,405$ & 0,603 \\
\hline & & Gelir/ücret/ para & $-1,190 *$ & $\mathbf{0 , 0 2 2}$ \\
\hline & \multirow[t]{3}{*}{ Gelir/ücret/para } & Huzur & $-0,199$ & 0,943 \\
\hline & & Potansiyeli gerçekleştirme & 0,405 & 0,603 \\
\hline & & İşi severek yapma & $-0,786$ & 0,337 \\
\hline
\end{tabular}

Not. $* 0.05$ düzeyinde anlamlı farklılık 
avukatlara göre olumlu duygularının daha yüksek olduğu sonucunu vermektedir. Bu bulguların aksine literatürde, yüksek gelir/ücret/paraya ilişkin için hissedilen baskıların yanlış varsayımlara dayandığ ve bu durumun mutluluk yaratmayacağ öngörülmektedir (Stetz, 2018). Literatürde ortaya çıkan birbirinden farklı sonuçların nedeni, hem mutluluk hem de ücret/gelir/paranın oldukça öznel olgular olmasından kaynaklanabilir. $\mathrm{Bu}$ nedenle yeni çalışmalarla bu konu desteklenebilir.

\section{SONUÇ ve TARTIŞMA}

Çalışmayı tercih eden ya da çalışmak zorunda olan insanların çoğu, işe sahip olmak ve çalışmak için önemli miktarda zaman harcar. Bu nedenle işleriyle ya da çalışmalarıyla ilgili hislerinin, tutum ve düşüncelerinin, algılarının yaşamları üzerinde önemli bir etkisi vardır (Stairs \& Galphin, 2010).

Araştırmada nicel araştırma bulgularına göre demografik özelliklere ilişkin yapılan analiz soncunda elde edilen sonuçta, özel sektör avukatlarının genel çalışma mutluluğunun $(3,07)$ ve olumlu duyguların $(3,16)$ ortalama, içsel doygunluğun verdiği mutluluğun yüksek $(3,71)$ düzeyde olduğu görülmektedir. Araştırmaya katılan avukatlar arasında işveren avukatlar ile işçi avukatların şirket avukatlarına göre olumsuz duygularının daha yüksek olduğu sonucuna varılmıştır. Ayrıca, işveren ve işçi avukatların şirket avukatlarına göre daha yüksek çalışma mutluluğuna sahip olduğu dikkat çekmektedir.

Araştırma sonucunda, kadın avukatların genel çalışma mutluluğu, olumlu duygular ve içsel çalışma mutluluğu ortalamalarının erkeklere göre daha yüksek; olumsuz duygular ortalamalarının daha düşük olduğu görülmektedir. Medeni durum bağlamında, evli avukatların genel çalışma mutluluğu, içsel doygunluğun verdiği mutluluk ve olumlu duyguları bekâr avukatlara göre daha düşük; olumsuz duygular ise; her iki grup için eşit düzeydedir. Öte yandan, olumlu duygular ile içsel doygunluğun verdiği mutluluk lisans mezunu avukatlar için yüksek lisans mezunu avukatlara göre daha yüksek; olumsuz duygular daha düşüktür. Demografik değişkenlerden çalışma biçimine göre olumlu duyguların, olumsuz duyguların ve içsel doygunluğun verdiği mutluluğun anlamlı bir farklılık göstermediği sonucuna varılmıştır.

Nitel araştırma kapsamında, özel sektör avukatlarının çalışma mutluluğunu potansiyellerini gerçekleştirme, çalışma ortamı koşulları, huzur, işi sevme, para/gelir/ücret ile ifade ettiği gözlenmiştir.
$\mathrm{Bu}$ ifadeler arasında en s1k dile getirilen ise; potansiyelini gerçekleştirmedir.

Nicel ve nitel araştırma sonuçları karşılaştırıldığı zaman; çalışma mutluluğunu, gelir/para/ücret ile ifade eden avukatların; genel çalışma mutluluğu $(3,24)$ ve olumlu duygular $(3,89)$ ortalamalarının; çalışma mutluluğunu potansiyelini gerçekleştirme, çalışma ortamı koşulları, huzur ve işi sevme ile ifade edenlere göre daha yüksek olduğu sonucuna varılmıştır. Çalışma ortamının, çalışma mutluluğunu ifade ettiğini belirten avukatlar arasında ise; olumsuz duygular en düşük $(2,28)$; içsel doygunluğun verdiğ $(3,76)$ ortalamaya sahiptir. Öte yandan, çalıșma mutluluğunu huzur ile ifade eden avukatlar ile potansiyelini gerçekleştirmeyi ifade eden avukatlar arasında olumlu duygulara göre anlamlı bir farklılık olduğu görülmektedir. Çalışma mutluluğunu potansiyeli gerçekleştirme ile ifade eden avukatların huzur ile ifade eden avukatlara göre olumlu duyguları daha yüksektir. İşi severek yapmayı çalışma mutluluğu olarak ifade eden avukatlar ile huzur ve gelir/para/ücret olarak ifade eden avukatlar arasında da, olumlu duygular açısından anlamlı bir farklılık ortaya çıkmıştır. Bunun yanında, huzur ve para/ücret/gelir ile çalışma mutluluğunu ifadeleri eden avukatların işini severek yapma olarak ifade eden avukatlara göre olumlu duyguları daha yüksektir. Genel olarak sonuçlara bakıldığında, özel sektör avukatları arasında çalışma mutluluğunun, en fazla gelir/ücret/para, potansiyeli ortaya çıkarma, huzur ve işi sevme olarak algılandığ 1 görülmektedir. Tüm bulgular açısından genel bir değerlendirme yapmak gerekirse, gelecek araştırmalarda ülkemizde çalışma mutluluğu araştırmaları sektör ve örneklem çeșitliliğinde zenginleştirilerek nicel ve nitel veri zenginliği sağlanmasına yönelik çalışmalar yapılabilir. Demografik değişkenler özelinde çalışma mutluluğu araştırma ve projeleri yapılarak bölgesel, sektörel ve ulusal ölçekte araştırmalar yapılabilir. Özel sektör avukatları arasında yapılan bu çalışma kamu avukatları arasında da yapılarak karşılaştırmalar yapılabilir. Ayrıca, çalışma mutluluğuna ilişkin teoriden uygulamaya yönelik modeller ve eğitim programları tasarlanabilir. Böylece, çalışma mutluluğu için daha fazla farkındalık sağlanacağı öngörülebilir.

\section{ETÍK BAYANATI}

Destek Bilgisi: Bu çalışma, kamu, ticari veya kar amacı gütmeyen kuruluşlar gibi herhangi bir organizasyondan destek almamıştır.

Çıkar Çatışması: $\mathrm{Bu}$ eser icin herhangi bir çıkar çatışması yoktur.

Etik Onayı: $\mathrm{Bu}$ çalışmada gerçekleştirilen tüm prosedürler, kurumsal ve / veya ulusal araştırma komitesinin etik standartlarına uygundur. 


\section{KAYNAKÇA}

Adelmann, P. K. (1987). Occupational complexity, control, and personal income: Their relation to psychological well-being in men and women. Journal of Applied Psychology, 72(4), 529-537.

Andrew, S. S. (2011). S.M.I.L.E.S.: The differentiating quotient for happiness at work. www.happiestminds.com, 10.08.2019.

Andrie, A. M. (2011). Positive and negative emotions within the organizational context. Global Journal of Human Social Science, XI(IX), 27-39.

Arthur, V. C. (1987). Job satisfaction and its relationship to gender, career orientation, and childcare needs among white collar and blue collar residence hall employees (Unpublesed Retrospective Theses and Dissertations. 8611)

Arslan, Y. \& Polat, S. (2017). Adaptation of well-being at work scale to Turkish. Kuram ve Uygulamada Eğitim Yönetimi, 23(4), 603-622.

Atkinson, C. \& Hall, H. (2011). Flexible working and happiness in the NHS. Employee Relations, 33(2),88105.

Barlow, J. \& Brooks, J. (2018). Lawyer Happiness Survey. Nimble Original Research, https://static1.squarespace.com/static/571acf3155598 6bfe84f0d93/t/5a99a361085229db9df8c4de/1520018 277432/2018LawyerHappiness-Results.pdf 02.07.2019.

Bataineh, K. A. (2019). Impact of work-life balance, happiness at work, on employee performance. International Business Research, 12(2), 99-112.

Byrne, M., Chughtai, A. A., Flood, B. \& Willis, P. (2012). Job satisfaction among accounting and finance academics: empirical evidence from Irish higher education institutions. Journal of Higher Education Policy and Management, 34(2),153-167.

Bhattacherjee, A. (2012). Social science research: principles, methods and practices. Textbooks Collection

http://scholarcommons.usf.edu/oa_textbooks/3, 26.01. 2019.

Bir avukat yanında, avukatlık ortaklığında veya avukatlık bürosunda ücret karşılığı birlikte çalışan avukatlar yönergesi,

https://www.barobirlik.org.tr/dosyalar/duyurular/2013 0924 yonerge.pdf, 08.04.2019.

Campbell D. T. \& Fiske, D. W. (1959). Convergent and discriminant validation by the multitrait-multimethod matrix. Psychological Bulletin, 56(2), 81-105.

Csikszentmihalyi, M. (1990). Akış : Mutluluk bilimi. Amazon Media EU S.à r.l.
Colombo, L. \& Zito, M. (2014). Demands, Resources and the Three Dimensions of Flow at Work. A Study among Professional Nurses. Open Journal of Nursing. 4, 255-264.

David, T. (2011). Can lawyers learn to be happy?. The Practical Lawyer, http://files.alicle.org/files/periodical/articles/TPL1108_David.pdf 11.09.2019.

Davis-Laack, P. (2017). What Makes Lawyers Happy? It's Not What You Think. https://www.forbes.com/sites/pauladavislaack/2017/1 2/19/what-makes-lawyers-happy-its-not-what-youthink/\#77f14b6317e5 02.04.2019.

Diener, E. (2000). Subjective well-being: The science of happiness and a proposal for a national index. American Psychologist, 55(1), 34-43.

Eckleberry-Hunt, J., Kirkpatrick, H., Taku, K., Hunt, R. \& Vasappa, R. (2016). Relation Between Physicians' Work Lives and Happiness. Southern Medical Journal, 109(4), 207-212.

Erselcan, C. \& Süral Özer, P. (2018). İş doyumunun performansa etkisinde mutluluğun aracilık rolü üzerine bir araştırma. Girişimcilik ve Kalkınma Dergisi, 13(2), 148-165.

Ersoy, A. \& Ehtiyar, V. R. (2017). Happiness at work. In R. Efe, Penkova, R., Wendt, J.A., Saparov, K.T. \& Berdenov, J.G. (Eds), Developments in Social Sciences (pp. 375-381). St. Kliment Ohridski University Press, Sofia.

Fernández, J. L. F., Gamez, M. A. F., Aragón, N. D. Q. \& Gil, A. C. (2017). Happiness at work, business behaviour, and worker perceptions: A case study. Ramon Llull Journal of Applied Ethics, 8, 23-34.

Fisher, C. D. (2010). Happiness at work. International Journal of Management Reviews, 12(4), 384-412:

Fredrickson, B. L. (2004). The broaden-and-build theory of positive emotions. Philosophical Transactions of the Royal Society of London, 359(1449), 1367-1377.

Golparvara, M. \& Abedini, H. (2014). A comprehensive study on the relationship between meaning and spirituality at work with job happiness, positive affect and job satisfaction. Management Science Letters, 4(1), 255-268.

Grant, A. M., Christianson, M. K. \& Price, R. H. (2007). Happiness, Health, or Relationships? Managerial Practices and Employee Well-Being Tradeoffs. Academy of Management Perspectives, 21(1), 51-63.

Gunnell, M. (2016). Research methodologies: A comparison of quantitative, qualitative and mixed methods.

https://www.linkedin.com/pulse/researchmethodologi es-comparison-quantitative-mixed-methods-gunnell 
Gürseler, G. (2006). Bir avukat yanında aylıklı olarak çalışan avukatın durumunun avukatlık yasası açısından değerlendirilmesi. Türkiye Barolar Birliğ $i$ (TBB) Dergisi, 63, 67-71.

Jennings, P. A. \& Greenberg, M. T. (2009). The prosocial classroom: Teacher social and emotional competence in relation to student and classroom outcomes. Review of Educational Research, 79(1), 491-525.

Joo, B. K. \& Lee, I., (2017). Workplace happiness: Work engagement, career satisfaction, and subjective wellbeing. Evidence-based HRM: a Global Forum for Empirical Scholarship, 5(2), 206-221.

Judge, T. A., Thoresen, C. J., Bono, J. E. \& Patton, G. K. (2001). The job satisfaction-job performance relationship: A qualitative and quantitative review. Psychological Bulletin, 127(1), 376-407.

Kaplanoğlu, E. (2014). Mesleki stresin temel nedenleri ve muhtemel sonuçları: Manisa ilindeki SMMM'ler üzerine bir araştırma. Muhasebe ve Finansman Dergisi, 1(1), 131-150.

Keser, A. (2018). İşte mutluluk araştırması. Paradoks Ekonomi. Sosyoloji ve Politika Dergisi, 14(1), 43-57.

Khanna, N. \& Singh, N. (2017). Happiness of employees at work in manufacturing industry, India. International Research Journal of Management Science \& Technology, 8(6),121-128.

Kinicki, A. J., McKee-Ryan, F. M., Schriesheim, C. A. \& Carson, K. P. (2002). Assessing the construct validity of the job descriptive index: A review and metaanalysis. Journal of Applied Psychology, 87(1), 1432.

Lane, R. E. (1992). Work as "disutility" and money as "happiness": Cultural origins of a basic market error. The Journal of Socio-Economics, 21(1), 43-64.

Levinson, D. J. (1986). A conception of adult development. American Psychologist, 41(1), 3-13.

Levit, N. (2010). Five myths about happy lawyers. US: Oxford University Press.

Levit, N. \& Linder, D. (2010). The happy lawyer: Making a good life in the law. US: Oxford University Press.

Mason, J. (2006). Six strategies for mixing methods and linking data in social science research. Working Paper, Real Life Methods Working Papers: Six strategies for mixing methods and linking data. NCRM Working Paper Series, 4(6), 1- 12.

Milhouse, V. H. (2005). Women, organizational development, and the new science of happiness. Advancing Women in Leadership Online Journal, 21, 1-16.
Miles, M. B. \& Huberman, A. M. (1994). An expanded sourcebook: Qualitative data analysis. Thousand Oaks, CA: SAGE Publications, Inc.

Morse, J. M. (2003). The paradox of qualitative research design. Qualitative Health Research, 13(10),13331336.

Nam, M. H. \& Kwon, Y. C. (2013). Factors Influencing Happiness Index of Hospital Nurses. Journal of Korean Academy of Nursing Administration, 19(3), 329-339.

Ongkana, K. (2006). Relationships between personal factors, self esteem, work environment, and joy at work of staff nurses, private hospitals, Bangkok metropolis. (Unpublised Master Thesis). Chulalongkorn University.

Onwuegbuzie, A. J. \& Johnson, R. B. (2004). Mixed method and mixed model research. In Johnson, R.B., Christensen, L.B. (Eds.), Educational Research: Quantitative, Qualitative, and Mixed Approaches (pp. 408-431). Allyn and Bacon, Needham Heights, MA.

Özdemir, A. (2010). Yönetim biliminde ileri araştırma yöntemleri ve uygulamalar. İstanbul: Beta Basım A.Ş.

Paschoal, T. \& Tamayo, A. (2008). Construction and validation of the work well-being scale. Avaliação Psicológica, 7(1), 11-22.

Patton, M. (1990). Qualitative evaluation and research methods. Beverly Hills, CA: Sage.

Poopanit, A. (2008). Happiness at work index of personnel of the Office of the Rector Thammasat University (Unpublished Master's Thesis). Faculty of Social Administration, Bangkok.

Porter, L, W., Lawler, E. E. \& Hackman. J. R. (1975). Behavior in Organizations. New York: McGraw-Hill.

Proaktif Hukuk ve Danismanlik. Sirket avukati https://www.proaktifhukuk.com/sirket avukati.html, 08.04.2019).

Pryce-Jones, J. (2010). Happiness at work: Maximizing your psychological capital for success. Malden, MA: Wiley-Blackwell.

Riggio, R. E. (2016). 5 Negative workplace emotions and their effects on Us. Psychology Today. https://www.psychologytoday.com/intl/blog/cuttingedge-leadership/201603/5-negative-workplaceemotions-and-their-effects-us

Rodríguez-Muñoza, A. \& Sanz-Vergel, A. (2013). Happiness and well-being at work: A special issue introduction. Journal of Work and Organizational Psychology, 29(3), 95-97.

Salas-Vallina, A. \& Alegre, J. (2018). Happiness at work: Developing a shorter measure. Journal of 
Management \& Organization, Published online by Cambridge University Press, 1-21.

Saari, L. M. \& Judge, T. A. (2004). Employee attitudes and job satisfaction. Human Resource Management, 43(4), 395-407.

Sartori, D. \& Catalano, G. (2013). Infrastructure investment long term contribution: Economic Development and Wellbeing. Working Papers from Centre for Industrial Studies (CSIL). https://www.csilmilano.com/docs/WP2013_01.pdf 01.09.2019.

Seligman, M. E. P.,Verkuil, P. R. \& Kang, T. H. (2001). Why lawyers are unhappy. Cardozo Law Review, 10(1), 50-65.

Semaan, A. (2018). A review: The happy lawyer: making a good life in the law. American Bar Association. https://www.americanbar.org/groups/litigation/commi ttees/woman-advocate/practice/2018/book-reviewthe-happy-lawyer-making-a-good-life-in-the-law/ 01.08.2019.

Sloan, M. M. (2012). Controlling anger and happiness at work: An examination of gender differences. Gender, Work and Organization, 19(4), 371-391.

Stairs, M. \& Galpin, M. (2010). Positive engagement: From employee engagement to workplace happiness. In P. A. Linley, S. Harrington \& N. Garcea (Eds.), Oxford handbook of positive psychology and work (pp. 155-172). New York, NY, US: Oxford University Press.

Stetz, M. (2018). Where the HAPPiEST lawyers work. The National Jurist. https://www.legalmarketingblog.com/files/2019/01/N ational-Jurist-Where-the-Happiest-Lawyers-Work.pdf 11.09.2019.

Tahlil Azim, M., Haque, M. M. \& Chowdhury, R. A. (2013). Gender, marital status and job satisfaction an empirical study. International Review of Management and Business Research.

Tan, A. G. \& Majid, D. (2011). Teachers' perceptions of creativity and happiness: A perspective from Singapore. Procedia - Social and Behavioral Sciences, 15(1), 173-180.

Tashakkori, A. \& Teddlie, C. (2010). Handbook of mixed methods in social \& behavioral Research. Los Angeles. SAGE.

Tay, L., Kuykendall L. \& Diener, E. (2015). Satisfaction and Happiness - The Bright Side of Quality of Life. In: Glatzer W., Camfield L., Møller V., Rojas M. (Eds.), Global Handbook of Quality of Life (pp.839853). International Handbooks of Quality-of-Life. Springer, Dordrecht.
The Positive Psychology Program (2016). Positive Emotions: A List of 26 Examples \& Definition in Psychology. https://positivepsychologyprogram.com/positiveemotions-list-examples-definitionpsychology/\#definition-positive-emotions 03.04.2019

Tosten, R., Avc1, Y. E. \& Şahin, E. (2017). The Relations between the organizational happiness and the organizational socialization perceptions of teachers: The sample of physical education and sport. European Journal of Educational Research, 7(1), 151-157.

Warr, P. B. (2007). Work, happiness and unhappiness. London: Laurence Erlbaum Associates.

Warr, P.B. (2017). Happiness and mental health: A framework of vitamins in the environment and mental processes in the person. In J. C. Quick and C. L. Coop (Eds.), Handbook of stress and health: A guide to research and practice (pp. 57-74). London and New York: Wiley.

Wolfrum, T. (2010). The happy lawyer, making a good life in the law: Is happiness enough? Journal of the American Academy of Matrimonial Lawyers, 23(1), 441-451.

Yıldırım, A. (1999). Nitel araștırma yöntemlerinin temel özellikleri ve eğitim araştırmalarındaki yeri ve önemi. Eğitim ve Bilim, 23(112), 7-17. 